\title{
Determination of volatiles in volcanic rocks and minerals with a Directly Coupled Evolved Gas Analyzing System (DEGAS) - Part I: Interpretation of degassing profiles (DEGAS-profiles) of minerals and rocks on the basis of melting experiments
}

\author{
Klaus Heide and Christian M. Schmidt \\ Institute of Geosciences, University of Jena, Germany
}

\begin{abstract}
Volatile components in magma strongly influence many physical properties of melts and minerals. The temperature resolved degassing analysis of volcanic crystalline and vitreous rocks gives detailed information about volatile compounds in the melt. A special high-temperature mass-spectrometry device in combination with a thermo-balance allows a quantitative determination of different volatile species. It enables a differentiation between the primary gas content in the magma and the gas released from decomposition of secondary alteration products. The gas release profiles give the following indications: i) during the littoral explosions of Pahoehoe lava the content of volatiles is not changed by interaction with air or sea water; ii) the degassing profiles of vitreous black sand verify the primary content of volatiles in the erupted melt, only $\mathrm{CO}_{2}$ was detected; iii) the oxygen release profile gives significant indications for oxygen undersaturation of the erupted magma; iv) remelting of black sand in air at $1450^{\circ} \mathrm{C}$ for $0.45 \mathrm{~h}$ causes an oxygen saturation of the basaltic melt; v) remelting of black sand in argon atmosphere confirms the oxygen undersaturation of the melt; vi) remelting of black sand-black shale mixtures affects a significant change in the degassing profiles, especially in $\mathrm{CO}_{2}$-release. With the first investigations we can demonstrate that gas release curves of volcanic rocks are qualified for a) detection of the primary gas content of erupted magma; b) detection of alteration processes of the igneous glass; $\mathrm{c}$ ) detection of contamination of the magma with adjacent rocks.
\end{abstract}

Key words volatiles - magmatic rocks - basaltic glass - degassing - Hawaiian lava - remelting - black sand

\section{Introduction}

The analysis of volatiles in natural whole rocks has historically attracted little attention

Mailing address: Dr. Klaus Heide, Institute of Geosciences, University of Jena, Burgweg 11, D-07749 Jena, Germany; e-mail: ckh@rz.uni-jena.de from igneous petrologists, in contrast to major-, trace-elements and isotope analysis. As Caroll and Holloway (1994) wrote (1.1): «the words of Bowen 1928 are still broadly applicable ... to many petrologists a volatile component is exactly like a Maxwell demon; it does just what one may wish it to do».

The LOI (Loss On Ignition) is in many current publications the only information about volatiles in natural samples. Special analytical methods as well as KFT, SIMS or FTIR have been developed for several volatile species. DEGAS was developed in the last 20 years for a simultaneous determination of complex mix- 
tures of volatiles. This method has been used with success to solve problems of quality in glass production by uncontrolled formation of bubbles in the melt (Heide et al., 2000). It was demonstrated by systematic studies of industrial and laboratory produced specimens that a quantification of volatiles dissolved in industrial glass as well as in the matrix of magmatic rocks is possible. This allows the discrimination of residual volatiles in whole rocks.

For individual gasses like water the results are in agreement with other analytical techniques such as SIMS, FTIR, LECO or KFT (Leschik et al., 2004). Unlike these volatilespecific techniques DEGAS allows us to determine the amount of all volatiles evolved from the glass or the minerals in a single run.

This contribution presents preliminary results of degassing experiments performed on remelted basaltic glasses. The aim of the paper is to show the technical potential of DEGAS in the study of magmatic degassing and to draw the attention of the geological community to the possibilities of our analytical technique.
It is well known that the degassing behaviour is related to solubility properties of different volatile species, depending on factors such temperature, pressure and composition.

It has been demonstrated that the degassing behavior of a silicate melt in vacuum conditions is a complex process of evolution of different volatile species (Heide, 1989; Stelzner and Heide, 1992). A systematic study of vitreous rims from specific positions in the borehole HSDP2 (Hawaiian Scientific Drilling Project II) by Heide and Schmidt (2003) gave detailed information about temperature ranges of degassing and the concentrations of volatile species. The degassing rate and the degassing mechanism (formation of bubbles or/and diffusion from the bulk) is different for different species. A new aspect is the phenomenon of oxygen emplacement in the melt. Such a decrease of the partial pressure of oxygen during the degassing experiment was frequently observed by DEGAS (Heide and Schmidt, 2003).

The amount of material needed is in the order of 10 to $100 \mathrm{mg}$, i.e. about the size of synthetic products obtained in experimental petrology (Geiger et al., 2001; Leschik et al., 2004).

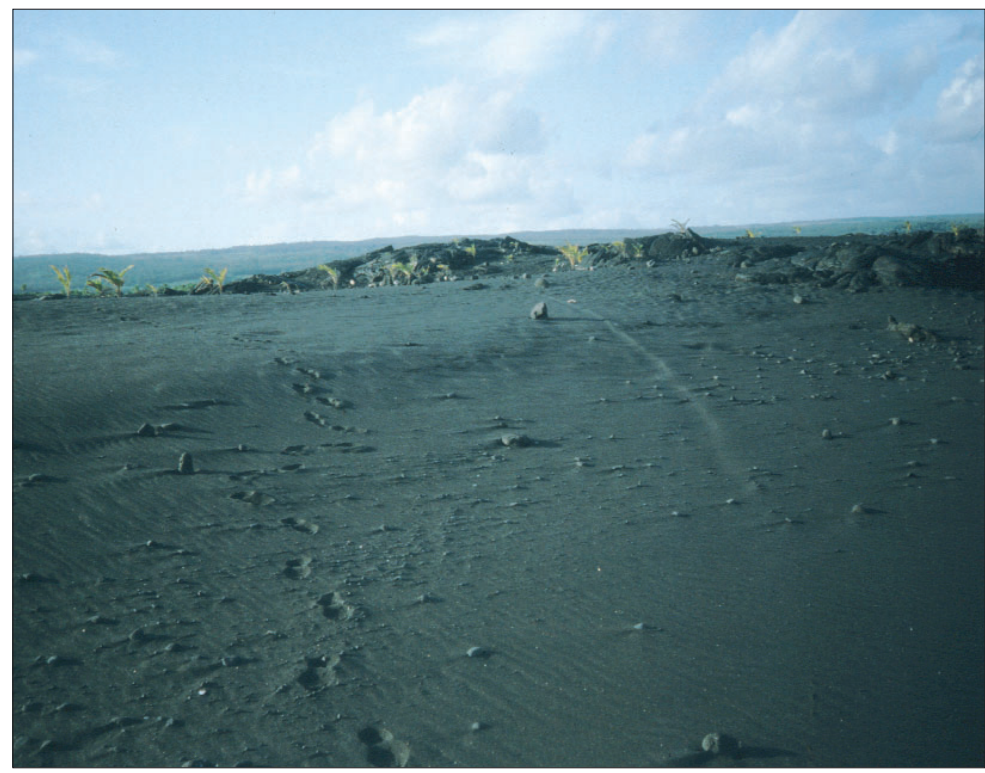

Fig. 1. Black sand beach, Kaimu, Big Island Hawaii, U.S.A. 
At present we are far from having a complete understanding of the degassing curves, but experiments have shown that the degassing profiles are sensitive regarding the following parameters: i) the melting temperature; ii) the starting materials for the melt, meaning the «raw materials» for the glass forming melt e.g. silicates, carbonates, sulfates, hydroxides, hydrates etc.; iii) the «fining agents» in the melt, meaning polyvalent ions which form oxygen during a redox reaction. In

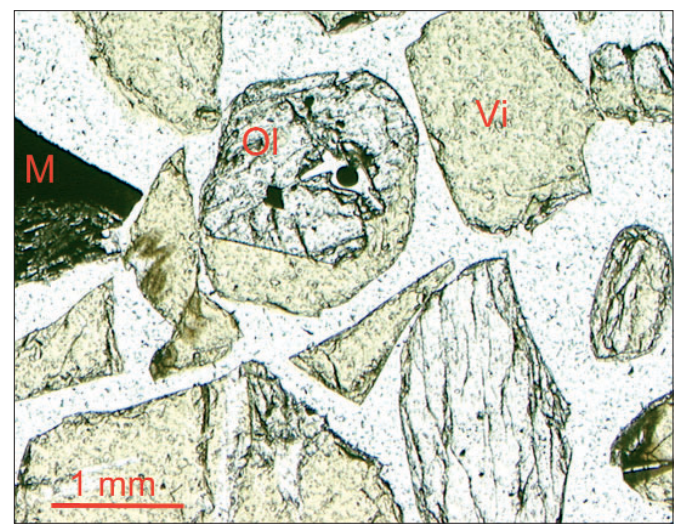

Fig. 2. Optical micrograph of vitreous particles from the black sand. Ol - olivine phenocrysts; $\mathrm{M}$ magnetite; $\mathrm{Vi}$ - vitreous matrix. case of natural systems the main process is the reduction of iron oxide

$$
\mathrm{Fe}_{2}^{\mathrm{III}} \mathrm{O}_{3} \rightarrow 2 \mathrm{Fe}^{\mathrm{II}} \mathrm{O}+\frac{1}{2} \mathrm{O}_{2} .
$$

This knowledge coming from industrial use allows us to ask the questions:

- Which results can be obtained from the degassing behavior of a natural volcanic glasses or rocks?

- Which effects result from the smelting of sedimentary rocks from the lithosphere in the extrusive volcanic melt?

\section{Experimental procedures}

\subsection{Samples and treatment}

The volcanic glasses studied here were sampled in 1999 from the black sand beaches of Kalapana (Kaimu), Big Island, Hawaii. The glassy volcanic debris was formed during the littoral explosions of Pahoehoe lava flows at Kaimu in 1990 and 1991 (fig. 1). As shown in fig. 2 the single black particles consist of a brownish fresh glass with euhedrial crystals of olivine and magnetite. These vitreous fragments are similar to glassy rims on the basaltic lava (Heide and Schmidt, 2003).

Table I. Chemical composition of Hawaiian basaltic lava.

\begin{tabular}{ccccc}
\hline \hline & $\begin{array}{c}\text { Tholeiitic Hawaiian basalt } \\
\text { (average, Macdonald } \text { et al., 1983) }\end{array}$ & $\begin{array}{c}\text { Hawaian shield } \\
\text { basalt (Bevens and } \\
\text { Wright, 1992) }\end{array}$ & $\begin{array}{c}\text { Kaimu black } \\
\text { sand (XRF) }\end{array}$ & $\begin{array}{c}\text { Remelted black sand } \\
\text { (Kaimu), vitreous } \\
\text { matrix (EDX) }\end{array}$ \\
\hline $\mathrm{SiO}_{2}$ & 49.4 & 48 & 51.0 & 47.6 \\
$\mathrm{TiO}_{2}$ & 2.5 & 3 & 2.5 & 2.2 \\
$\mathrm{Al}_{2} \mathrm{O}_{3}$ & 13.9 & 14 & 13.0 & 11.2 \\
$\mathrm{Fe}_{2} \mathrm{O}_{3}$ & 3.0 & 3 & 12.8 total & - \\
$\mathrm{FeO}$ & 8.5 & 8 & - & 12.7 total \\
$\mathrm{MnO}$ & 0.2 & 0.1 & 0.2 & 0.5 \\
$\mathrm{MgO}$ & 8.4 & 7 & 8.7 & 15.9 \\
$\mathrm{CaO}$ & 10.3 & 9 & 11.0 & 8.6 \\
$\mathrm{Na}$ & 2.1 & 3 & 2.2 & 1.7 \\
$\mathrm{~K}_{2} \mathrm{O}$ & 0.4 & 1 & 0.4 & 0.4 \\
$\mathrm{P}_{2} \mathrm{O}_{5}$ & 0.3 & 0.5 & 0.2 & -
\end{tabular}




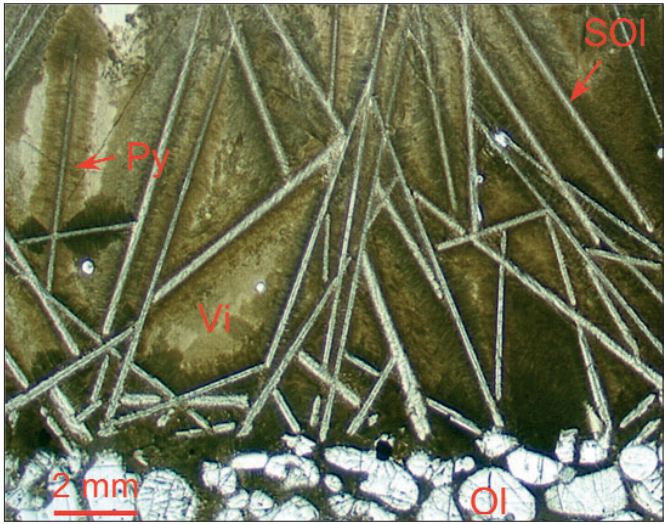

Fig. 3. Optical micrograph of remelting product from black sand. Melting condition: $1400^{\circ} \mathrm{C}, 0.45 \mathrm{~h}$ in air; $\mathrm{Ol}$ - residual olivine phenocrysts; SOL- skeletal olivine

The chemical composition of glassy volcanic debris is characterized by tholeiitic lava type (table I).

Particles between 2 and $6 \mathrm{~mm}$ size were separated from the bulk for remelting experiments. A black melt with a volume of $10 \mathrm{~cm}^{3}$ was obtained by heating in an alumina crucible at $1400^{\circ} \mathrm{C}$. The melting process was carried out for $0.45 \mathrm{~h}$ in an oxidizing (air) or inert (argon) atmosphere. As shown in fig. 3 a characteristic phase separation occurs in the melt. Olivine crystals from the starting material were concentrated on the bottom of the crucible. The bulk material is a brownish glass (table I) with inclusions of olivine and pyroxene crystals and magnetite dendrites. Olivine and pyroxene crystals show the characteristic spinnifex structure.

To demonstrate the influence of a remelting of sedimentary rocks in the basaltic melt 10 wt $\%$ of a powdered black shale was added to the starting mixture.

\subsection{Experimental techniques}

Evolved gas analysis was carried out using a special high-temperature mass-spectrometer (Heide et al., 2000). Measurements were performed under a vacuum of $10^{-3}$ to $10^{-4} \mathrm{~Pa}$ using a constant heating rate of $10 \mathrm{~K} / \mathrm{min}$ from Room Temperature (RT) to $1450^{\circ} \mathrm{C}$. The ion current for different mass/charge ratios $(m / z=1 \ldots 200)$ was recorded in a Multiple Ion Detection (MID) mode as a function of time by a Quadrupole Mass-Spectrometer (QMA-125 Balzers AG). Temperature was controlled by a type $S$ thermocouple at the bottom of the alumina crucible. The degassing process occurs under highly non-equilibrium conditions. Volatile species are rapidly removed from the sample and hence the probability for reverse reactions between the volatiles and the melt can be avoided. Furthermore, interactions between the evolved gas species are minimized and a determination of the primary evolved species is possible.

For degassing experiments we used carefully separated single particles with a total weight of about $20 \mathrm{mg}$.

In the following the gas release profiles of hydrogen, hydrocarbons (methane), water, carbon monoxide, carbon dioxide, oxygen, hydrogen chloride and sulfur dioxide are discussed.

\section{Results}

The degassing profiles of original black sand from Kaimu (I), remelting products in oxidizing (II) and argon atmosphere (III), and melting products from black sand mixed with $10 \mathrm{wt} \%$ black shale in oxidizing (IV) and argon atmosphere (V) are summarized in figs. 4 to 9 .

$\mathrm{H}_{2}\left(m / z 2=\mathrm{H}_{2}{ }^{+}=\right.$molecule ion of hydrogen $)-$ Samples (I) and (III) show a hydrogen-release above $1150^{\circ} \mathrm{C}$ with a broad maximum at $1310^{\circ} \mathrm{C}$ (fig. 4). Sample (II) shows an increase of hydrogen evolution above $1200^{\circ} \mathrm{C}$ up to $1450^{\circ} \mathrm{C}$ without a maximum. Samples (IV) and (V) are similar to (I) and (III).

Hydrocarbons (fragment ions from $\mathrm{CH}_{4}{ }^{+}=$ $=16$ like $\left.\mathrm{CH}_{3}{ }^{+}=m / z=15\right)-$ No significant release of hydrocarbons, here characterized by fragment ion $\mathrm{CH}_{3}{ }^{+}(\mathrm{m} / \mathrm{z}, 15)$ was detectable in any samples (fig. 5).

$\mathrm{H}_{2} \mathrm{O}\left(m / z=18=\mathrm{H}_{2} \mathrm{O}^{+}=\right.$molecule ion of water) - Only very small quantities of water evolved 

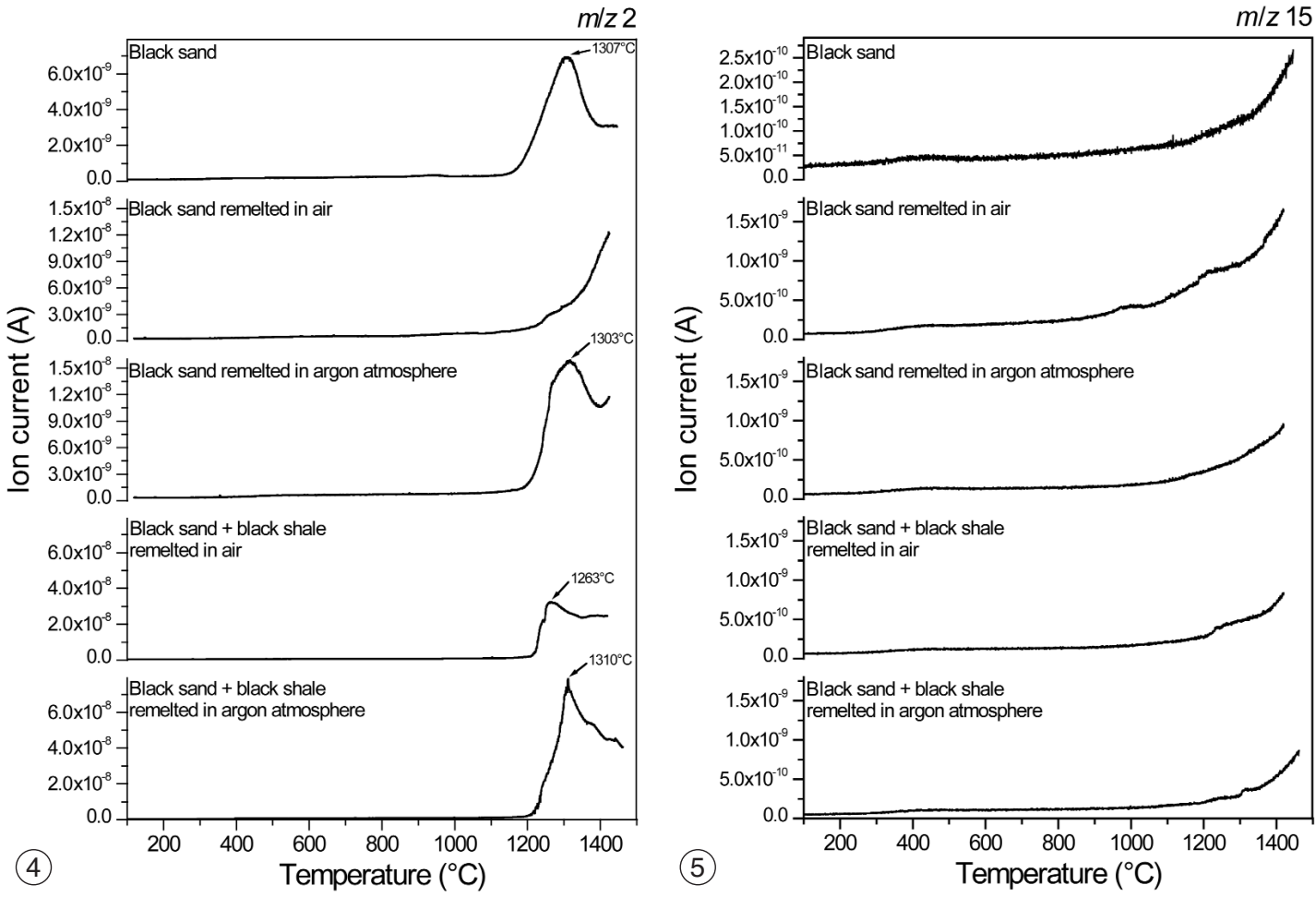

Fig. 4. Hydrogen $(m / z=2)$ release profiles from black sand and remelting products.

Fig. 5. Degassing profile of hydrocarbon fragment of methane $\mathrm{CH}_{3}{ }^{+}-(m / z=15)$ from black sand and remelting products.

from the original black sand sample (fig. 6). The small spikes at approximately $900^{\circ} \mathrm{C}$ and $1110^{\circ} \mathrm{C}$ result from bursting of bubbles. The decrease of partial pressure in the degassing profiles from black sand and black shale mixtures is due to chemical reactions in the melt.

$\mathrm{CO}, \mathrm{CO}_{2}$ and $\mathrm{N}_{2}(\mathrm{~m} / \mathrm{z}=28$ : molecule ions of $\mathrm{CO}$ and $\mathrm{N}_{2}$ as well as fragment ion of $\mathrm{CO}_{2} \mathrm{~m} / \mathrm{z}=$ $=44-16=28$ ) - For determination of CO-degassing a more complex analysis of degassing profiles is necessary (Schmidt and Heide, 2001, fig. 7). The intensity of molecule ion $\mathrm{CO}^{+}(\mathrm{m} / \mathrm{z}$ 28) can be superposed by the molecule ion of nitrogen $\mathrm{N}_{2}{ }^{+}(\mathrm{m} / \mathrm{z}, 28)$ and by the fragment ion $\mathrm{CO}^{+}$from the $\mathrm{CO}_{2}$ molecule. By comparison of the degassing profiles of $m / z=14$ (fragment ion $\mathrm{N}^{+}$or $\mathrm{CO}^{++}$, fig. 8) with the runs of $m / z 28$ and $\mathrm{m} / \mathrm{z} 44$ (molecule ion of $\mathrm{CO}_{2}$, fig. 9) a separation of $\mathrm{N}_{2}, \mathrm{CO}$ and $\mathrm{CO}_{2}$ is possible.

Most of the carbon dioxide evolved from the black sand by bubbling from 1050 up to $1130^{\circ} \mathrm{C}$. The degassing behavior is completely changed by remelting in air. Carbon dioxide evolved mainly by a diffusion process with a maximum diffusion rate at $1240^{\circ} \mathrm{C}$. Remelting in inert atmosphere shows a degassing by diffusion and by bubbling. Addition of black shale to the black sand shows similar degassing profiles as the samples from inert remelting. Only in these mixtures are traces of nitrogen observed in the melt, which escaped by bubbling at approximately $1200^{\circ} \mathrm{C}$ (see fig. 8). 

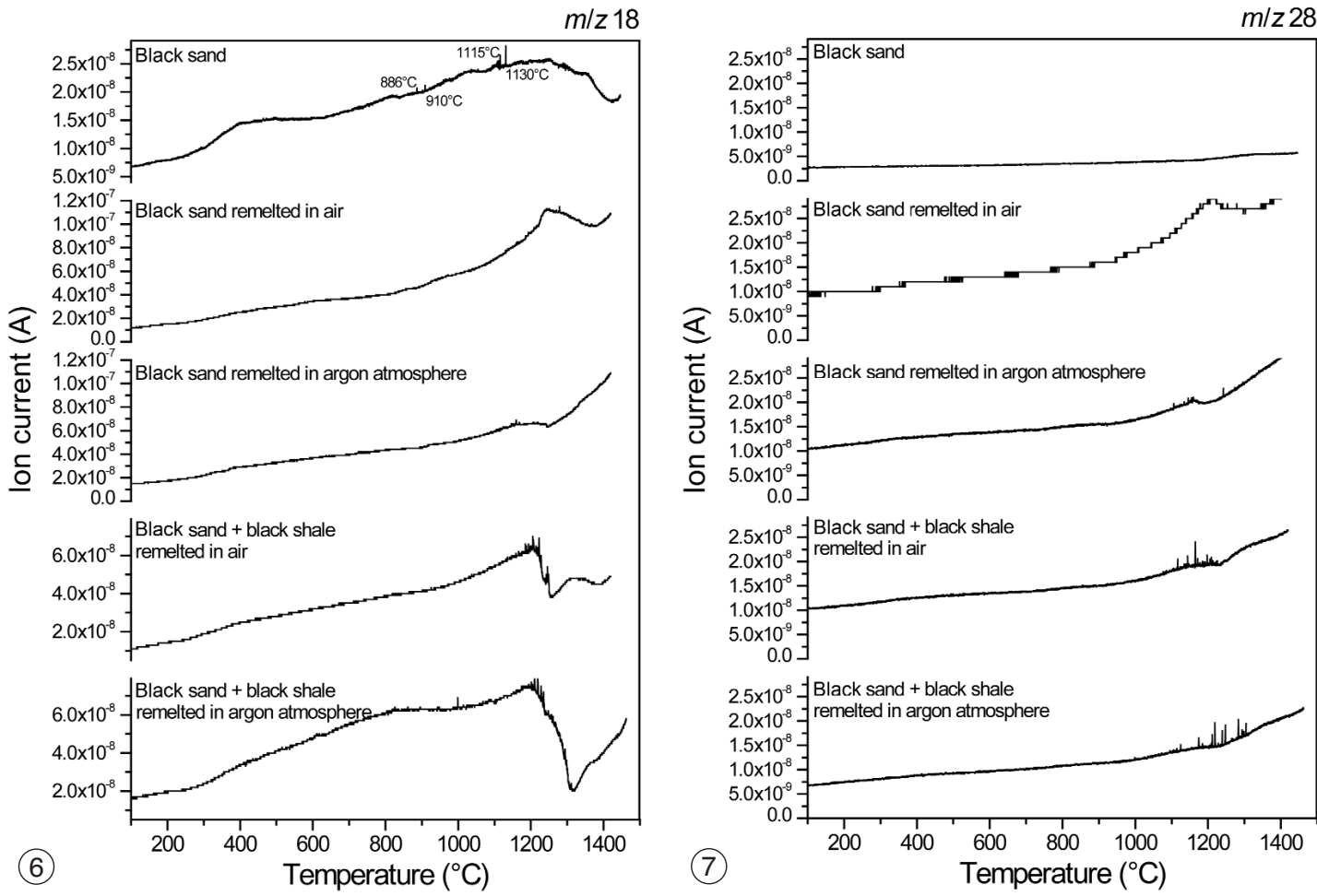

Fig. 6. Water release $(m / z=18)$ from black sand and remelting products.

Fig. 7. Change of partial pressure of the mass number $m / z=28$.

$\mathrm{O}_{2}\left(m / z=32=\right.$ molecule ion of ${ }^{16} \mathrm{O}_{2}{ }^{+}$and $\left.{ }^{32} \mathrm{~S}^{+}\right)$ - Especially interesting are the oxygen release curves $(\mathrm{m} / \mathrm{z} 32)$. As shown in fig. 10 during degassing of black sand the oxygen partial pressure decreases above $1100^{\circ} \mathrm{C}$ up to $1300^{\circ} \mathrm{C}$.

After remelting in air still above $1200^{\circ} \mathrm{C}$, oxygen releases from the melt by diffusion with a maximum at $1210^{\circ} \mathrm{C}$.

Gas release profiles of non-oxidizing melting products are similar to degassing of the natural sample.

Mixtures with black shales molten in oxidizing as well as non-oxidizing atmospheres show similar trends.

The discrimination between oxygen and sulfur is possible using specific fragment ions as well as $m / z=64$ for $\mathrm{SO}_{2}{ }^{+}$or $m / z=48$ for $\mathrm{SO}^{+}$ and by correlation of intensities of molecule ions with fragment ions (more details see in Heide, 1982).

$\mathrm{HCl}\left(m / z=36=\mathrm{H}^{35} \mathrm{Cl}^{+}\right.$molecule ion $)$- There is no indication of HCl-release in the case of the starting material from the beach (fig. 11). The small degassing peak from the in air remelted sample can be explained by a contamination of the sample from the air during the remelting process $(2 \mathrm{~h})$ in the laboratory furnace or by an inhomogeneity in the starting material. From the igneous sample $\mathrm{HCl}$ does not escape in the range of detection limit $\left(1 \times 10^{-12}\right.$ ion current is approximately equivalent to $100 \mathrm{ppb}$ using 50 $\mathrm{mg}$ of starting material).

$\mathrm{SO}_{2}\left(m / z=64=\right.$ molecule ion of $\mathrm{SO}_{2}{ }^{+}$or fragment ion of $\left.\mathrm{SO}_{3}{ }^{+}=m / z, 80-16\right)-$ No indication 

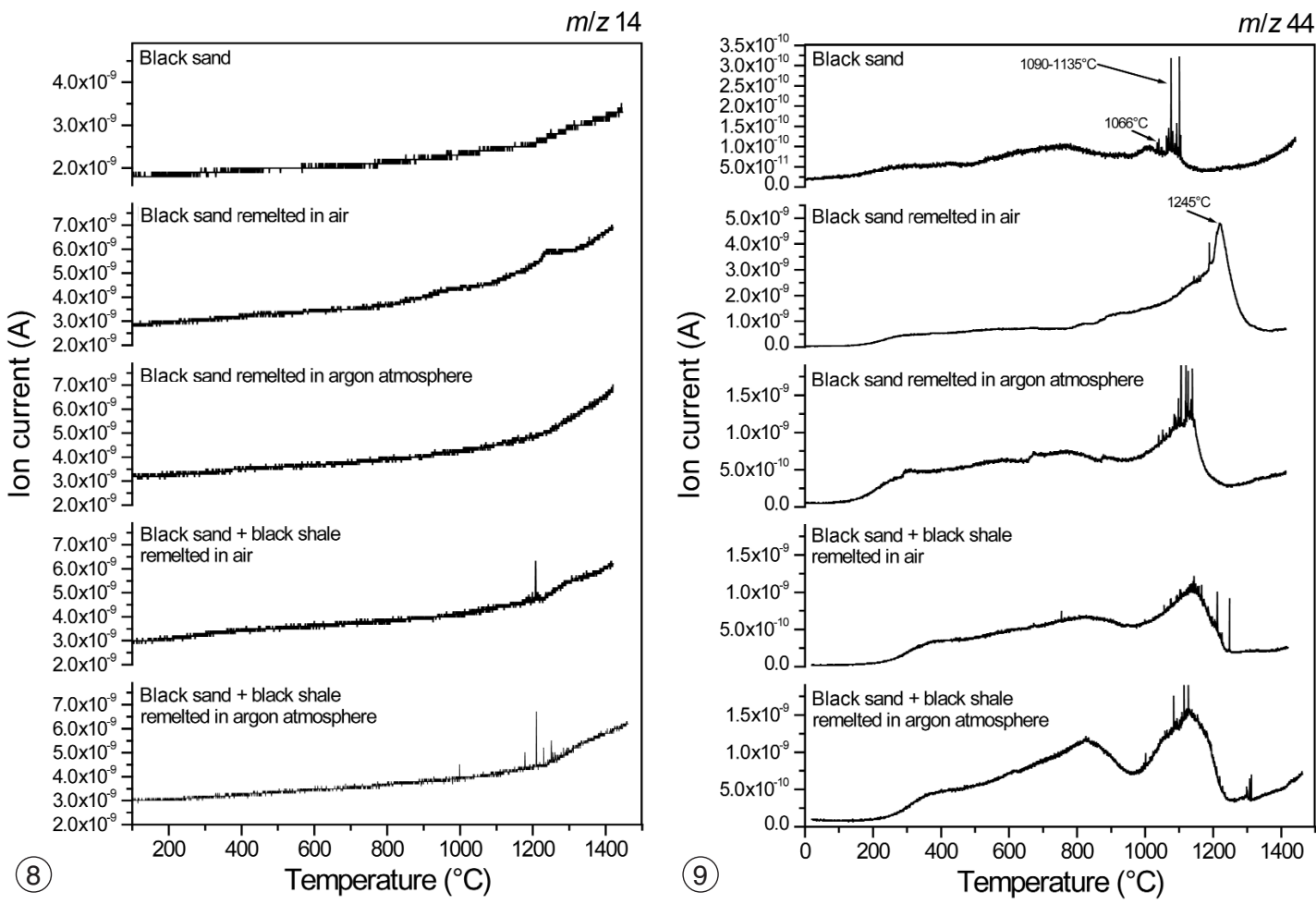

Fig. 8. Change of the partial pressure of the mass number $m / z=14$.

Fig. 9. $\mathrm{CO}_{2}$ release of black sand and remelting products.

of $\mathrm{SO}_{2}$-release is observed in the original sample from the beach. Very small quantities of sulfur oxides (detected as $\mathrm{SO}^{+}(\mathrm{m} / z=48)$ ) evolved from the remelted black sand samples only by bubbling (fig. 12). The small spikes in the temperature range between $1100^{\circ} \mathrm{C}$ and $1200^{\circ} \mathrm{C}$ result from bursting of bubbles.

To check the influence of olivine phenocrysts on the gas release, olivine crystals were separated from the glassy matrix.

As shown in fig. 13 the described technique allows a simultaneous characterization of escaped gases from the matrix glass as well as from the crystal inclusions. The olivine phenocrystals show a spiky evolution of $\mathrm{CO}_{2}$ in the range at $1000^{\circ} \mathrm{C}$, which can be explained by the decripitation of fluid inclusions in the xenocrysts.

\section{Discussion}

\subsection{Gas release from the black sand samples}

The degassing profiles from the littoral vitreous lava fragments give significant indications that the content of volatiles of magma was not changed by an interaction with air or sea water. From the magma $\mathrm{CO}_{2}$ only evolved by bubbling above $1000^{\circ} \mathrm{C}$ (fig. 9).

As shown in fig. 13 small quantities of $\mathrm{CO}_{2}$ evolved from olivine as spikes above $1000^{\circ} \mathrm{C}$ in the same temperature range as from the matrix glass. The formation of fluid inclusions in the olivine crystals and the solution of $\mathrm{CO}_{2}$ in the glass forming melt take place in the same temperature - pressure range. This is an important indication that the high temperature degassing 

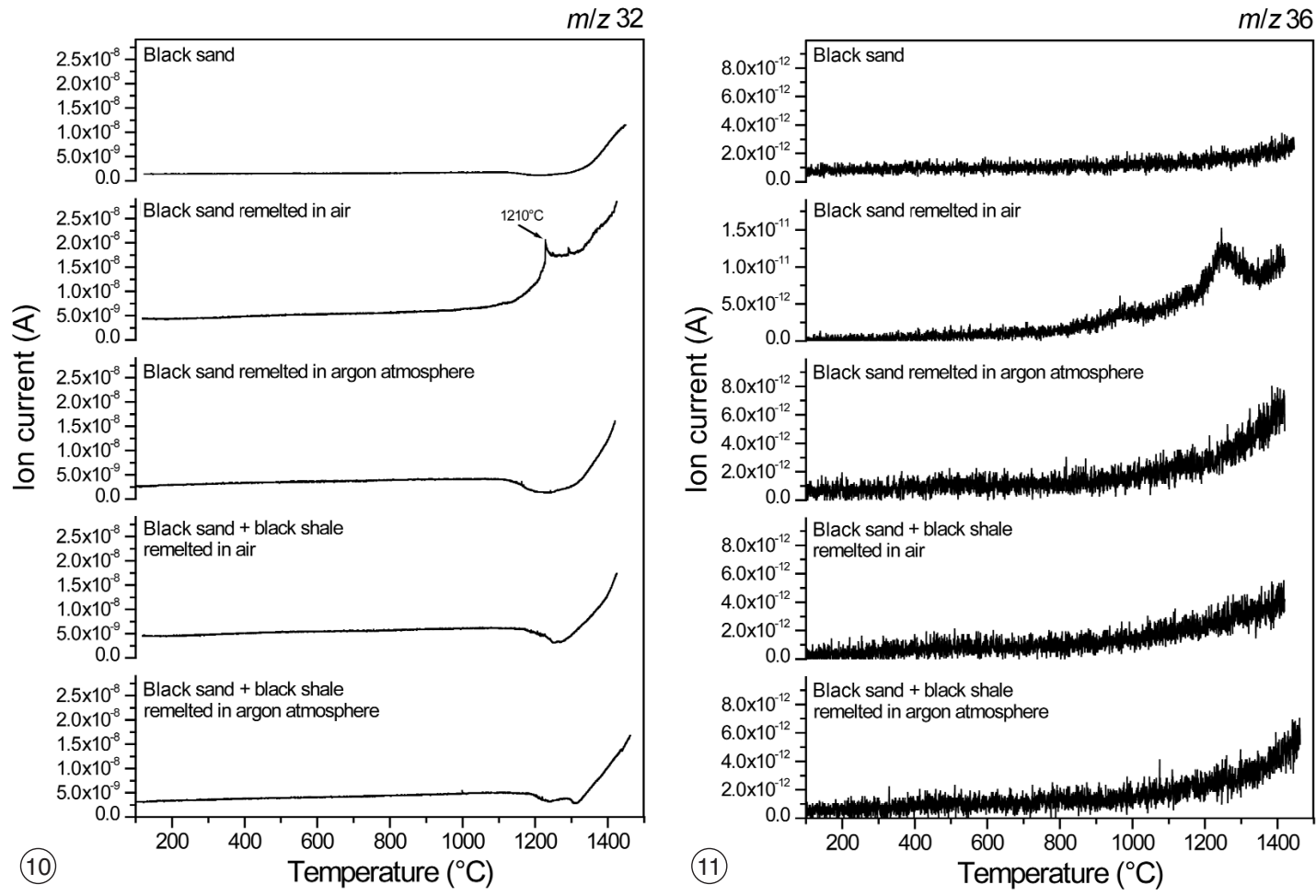

Fig. 10. Change of the partial pressure of mass number $m / z=32\left(\mathrm{O}_{2}^{+}\right)$.

Fig. 11. Change of the partial pressure of mass number $m / z=35\left({ }^{35} \mathrm{Cl}^{+}\right)$.

gives valuable information about the interaction of volatiles with the melt during the igneous process.

Furthermore the main $\mathrm{CO}_{2}$ volume evolved from the vitreous matrix in the temperature range between 500 and $600^{\circ} \mathrm{C}$. This is an unequivocal indication of a carbonate decomposition. A definite discrimination between carbon dioxide solved in the melt and from secondary carbonates is possible.

The non-detectable interaction of erupted lava with air or sea water was confirmed by the oxygen degassing profile. This agrees with the observation by Burkhard (2001) that no oxidation of Kilauea basalt glass is detectable. Furthermore Dixon and Clague (2001) describe a relatively dry plume component in the basaltic glasses from Loihi Seamount.
In addition, $\mathrm{HCl}$ release profiles give no indication for a contamination by sea water.

The $\mathrm{SO}_{2}$ release is an indication of a subsequent devolatilization of the magma during the eruption process.

Subaerially erupted Hawaiian magmas are characterized by sulfur contents of $100 \mathrm{ppm}$ at a $\delta^{34} \mathrm{~S}<0$. This may indicate loss of total sulfur and $\delta^{34} \mathrm{~S}$ compared to submarine Hawaiian magmas (700 ppm, $\delta^{34} \mathrm{~S}>0$ ), due to syn-eruptive degassing. This fractionation pattern also indicates that the degassing phase must be oxidized sulfur. $\mathrm{SO}_{2}$ commonly is the dominant phase at melt temperatures, although aside from $\mathrm{SO}_{2}$ and $\mathrm{SO}_{3}$, reduced species may occur (Gerlach and Graeber, 1985).

During the melting of the black sand particles under high vacuum conditions, the affinity 
of the melt to the oxygen concentration in the vacuum furnace is very strong. Oxygen was dissolved in the melt and by that the partial pressure of $\mathrm{O}_{2}$ in the furnace decreased. Thus the oxygen from the furnace devises was solved in the melt

$6 \mathrm{FeO}_{\text {in the melt }}+\mathrm{O}_{2 \text { from the sorroundings }} \rightarrow 2 \mathrm{Fe}_{2} \mathrm{O}_{3 \text { in the melt }}$.

From these preliminary results we suggest that the oxygen fugacity in the vacuum of the igneous glass should be lower than Fayalite Magnetite Quartz (FMQ)-buffer (see Gerlach, 1993). Conclusions for the oxygen fugacity of their mantle source require more detailed investigations with materials from experimental petrological studies (Leschik et al., 2004).

$m / z 48$

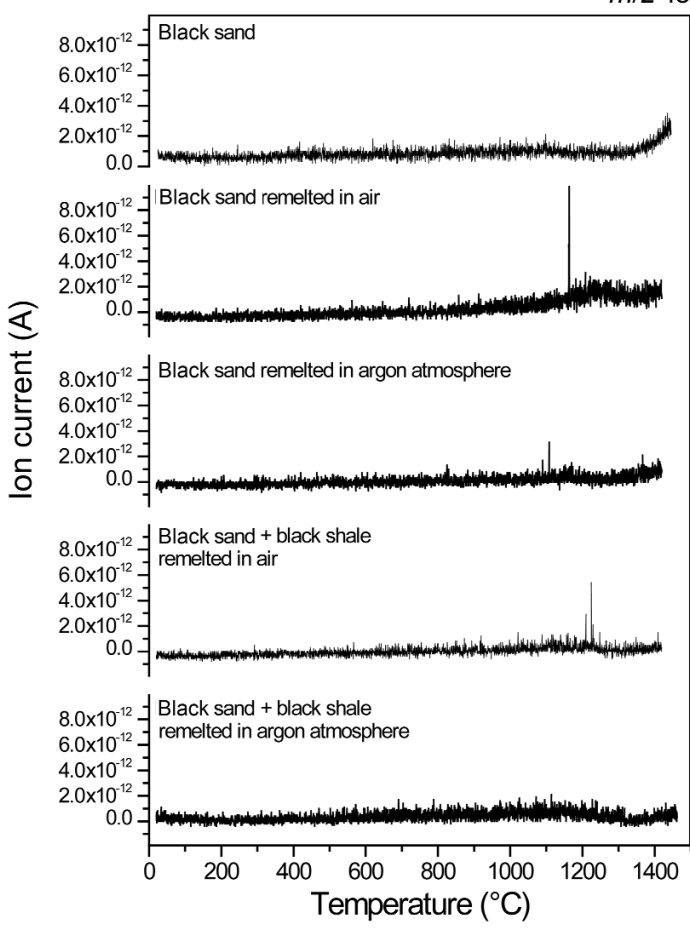

Fig. 12. Change of the partial pressure of mass number $m / z=48\left(\mathrm{SO}^{+}\right)$.

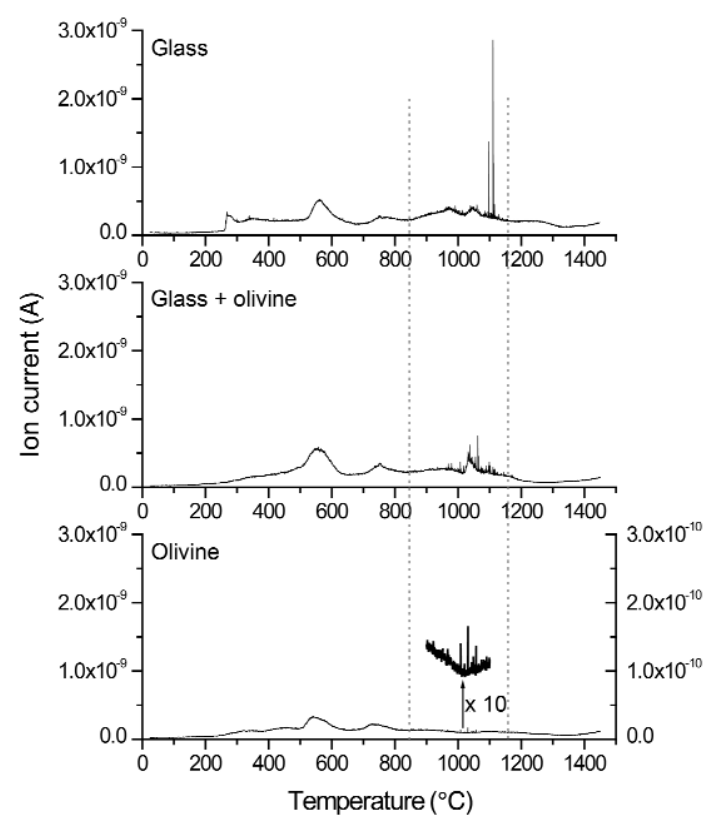

Fig. 13. $\mathrm{CO}_{2}$ release curves from black sand samples. A - vitreous matrix with olivine crystals; B vitreous matrix without olivine crystals; $\mathrm{C}$ - olivine crystals, separated from the vitreous matrix.

\subsection{Gas release from fresh erupted Etna lava}

As fig. 14 demonstrates the fresh erupted subaeric lava from Etna (eruption at 31.12.2002 south flank) shows a different oxygen release profile. After a minor decrease of the oxygen partial pressure above $1100^{\circ} \mathrm{C}$ the oxygen is released from the melt by bubbling. Further systematic studies are necessary to confirm this difference between the Island-Arc and the Ocean Island basalts. The strong oxygen affinity of the melt of both lavas also causes oxygen incorporation by remelting in air under normal pressure. From the maximum in the gas release curve (fig. 10) a significant change occurring in the oxidation state of the remelted samples can be concluded. The results are confirmed by the remelting experiments under inert atmosphere.

From our studies it is clear that the basaltic lava of Hawaii volcanism is strongly under-saturated with oxygen. 


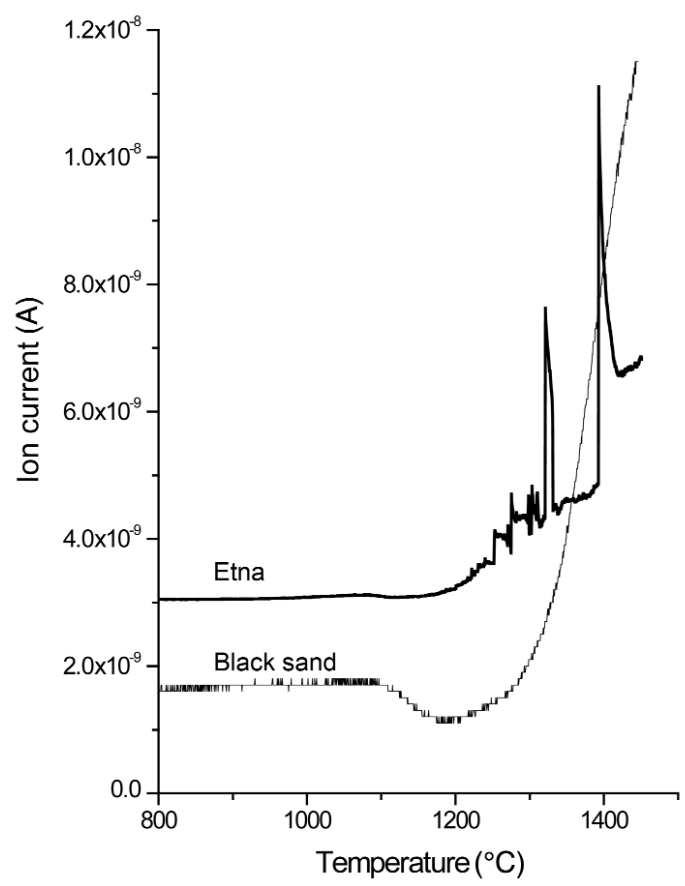

Fig. 14. Comparison of the oxygen release from Ocean Island basalt (Hawaii) and Island Arc basalt (Etna - 2002).

Crust contaminations by pelagic sediments can be excluded from our first results. For a final interpretation further systematic study is necessary.

With these first investigations we can demonstrate that gas release curves of volcanic rocks are qualified to i) characterize primary complex gas content of erupted magma in a range of several order of magnitude (between $0.1 \mathrm{ppm}$ and several \%); ii) characterize the formation temperature of fluid inclusions in xenocrysts and to determine simultaneous the complex composition; iii) detect and characterize alteration processes of the igneous glass and the secondary phases; iv) detect and characterize contamination of the magma with adjacent rocks; v) of particular interest is the detection of hydrogen as degassing product in a temperature range above $1000^{\circ} \mathrm{C}$ with a maximum at $1307^{\circ} \mathrm{C}$. Compared to MORB-lava degassing (Heide et al., 2000) we do not have indications for an inorganic formation of hydrocarbons (fig. 5).

From different studies we know that the pressure, temperature and compositionally-related dependence of volatile solubility is far from being simple (Behrens et al., 2001).

The solubility of $\mathrm{H}_{2} \mathrm{O}, \mathrm{S}, \mathrm{Cl}$, and $\mathrm{F}$ increases with increasing $\mathrm{SiO}_{2}$-content, these volatiles are thus enriched in residual melts (Carroll and Holloway, 1994; Dixon et al., 1995). While the solubility increases with increasing pressure, it decreases with increasing temperature (Williams and McBirney, 1979), whereby the effect of pressure is minor (Behrens and Jantos, 2001).

Surprisingly, oxygen frequently remains neglected in geochemical studies, although it is known from industrial glass melting processes that oxygen plays a crucial role during degassing of silicate melts (Jebsen-Marwedel and Brückner, 1980). Chemical equilibriums exist between volatiles and ions with polyvalencies in the melt. Different volatile molecules, like $\mathrm{CO}, \mathrm{CH}_{4}$ or $\mathrm{H}_{2}$, are thus formed depending on oxygen fugacity, temperature and pressure and may be resorbed again in the melt under changing conditions.

Thus it may be seen that the change in the redox equilibrium with temperature is an important kinetic factor during the degassing process of the melt. Reactions with polyvalent ions, especially $\mathrm{Fe}^{2+}$, yield oxygen bubbles in the high temperature range. The following reaction could occur between iron-rich olivine (fayalite) and the oxygen in the magma during heating under vacuum conditions in an open system, that means under extreme non-equilibrium conditions

$$
\begin{aligned}
& 2 \mathrm{Fe}_{3} \mathrm{O}_{4 \text { magnetite }}+3 \mathrm{SiO}_{2 \text { in the melt }} \Rightarrow 3 \mathrm{Fe}_{2} \mathrm{SiO}_{4 \text { fayalite }}+ \\
& +\mathrm{O}_{2 \text { gas (bubbles) }} \text {. }
\end{aligned}
$$

The oxygen bubbles act like a «fining» agent of a melt for all volatiles; thereby, oxygen effectively promotes the degassing of magma.

\section{Acknowledgements}

The authors wish to thank R. Moretti and B. Scaillet for helpful discussions and review of 
this report. S. Lenk assisted in obtaining the degassing profiles presented in this report. D. Schoeps and G. Voelksch are thanked for their assistance with XRF and EDX analysis.

\section{REFERENCES}

Behrens, H. and N. Jantos (2001): The effect of anhydrous composition on water solubility in granitic melt, Am. Mineral., 86, 14-20.

Behrens, H., M. Meyer, F. Holtz, D. Benne and M. NoVAK (2001): The effect of alkali ionic radius, temperature and pressure on solubility of water in $\mathrm{MAlSi}_{3} \mathrm{O}_{8}$ melts (M=Li, Na, K, Rb), Chem. Geol., 174, 275-290.

Bevens, D. and T.L. Wright (1992): Hawaii Volcanoes National Park (Hawaii Natural History Association), pp. 34.

BURKHARD, D.J.M. (2001): Crystallization and oxydation of Kilauea basalt glass: processes during reheating experiments, J. Petrol., 42, 507-527.

CARroll, M.R. and J.R. Holloway (Editors) (1994): Volatiles in magmas, Rev. Mineral., 30, pp. 517.

Dixon, J.E. and D.A. Clague (2001): Volatiles in basaltic glasses from Loihi seamount, Hawaii: evidence for a relatively dry plume component, J. Petrol., 42, 627-654.

Dixon, J.E., E.M. Stolper and J.R. Holoway (1995): An experimental study of water and carbon dioxide solubilities in mid-ocean ridge basaltic liquids, Part I. Calibration and solubility models, J. Petrol., 36, 911-939.

Geiger, C.A., N.-S. RAhmoun and K. Heide (2001): Volatiles in Cordierite, Beih. Eur. J. Mineral., 13 (1), pp. 60 .

GerLaCH, T.M. (1993): Oxygen buffering of Kilauea vol- canic gases and the oxygen fugacity of Kilauea basalt, Geochim. Cosmochim. Acta, 57, 795-814.

Gerlach, T.M. and E.J. Graeber (1985): Volatile budget of Kilauea volcano, Nature, 313, 273-277.

HeIDE, K. (1982): Dynamische Thermische Analysenmethoden (Leipzig, Deutscher Verlag für Grundstoffindustrie).

HeIDE, K. (1989): Thermogravimetric and mass spectrometric investigation of the decomposition and volatilization of raw materials by heating of a glass batch, J. Therm. Anal., 35, 305-318.

HeIDE, K. and C.M. SCHMidT (2003): Volatiles in vitreous basaltic rims, HSDP 2, big island, Hawaii, J. NonCryst. Solids, 323, 97-103.

Heide, K., K. Gerth and E. Hartmann (2000): The detection of an inorganic hydrocarbon formation in silicate melts by means of a direct-coupled-evolved-gas-analysis-system (DEGAS), Thermochim. Acta, 354 (1-2), 165-172.

JEBSEN-MARWEDEL, H. and R. BRÜCKNER (1980): Glastechnische Fabrikationsfehler (Springer-Verlag), pp. 640.

LeschiK, M., H. Behrens, M. WiEDEnBECK, N. WAGNer, K. HeIDE, H. Geissler, H.G. ReInHOlZ and G.-H. Frischat (2004): Determination of $\mathrm{H}_{2} \mathrm{O}$ and $\mathrm{D}_{2} \mathrm{O}$ contents in rhyolitic glasses using KFT, NRA, EGA, IR spectroscopy, and SIMS, Phys. Chem. Glasses, 45 (4), 238-251.

Macdonald, G.A., A.T. Aвbott and FL. Peterson (1983): Volcanoes in the Sea - The Geology of Hawaii (Honolulu, University of Hawaii Press), pp. 517.

SchmidT, C.M. and K. HeIDE (2001): Thermal analysis of hydrocarbons in paleozoic black shales, J. Therm. Anal. Calorim., 64, 1297-1302.

Stelzner, T. and K. HeIDE (1992): Degassing behavior of optical glasses, Glastechn. Ber., 65, 150-156.

Williams, H. and A.R. McBirney (1979): Volcanology (San Francisco, Freeman, Cooper), pp. 397. 